\title{
ROUGH Night:
}

\section{MULTISCALE ROUGHNESS INFLUENCES CORAL LARVAL SETTLEMENT}

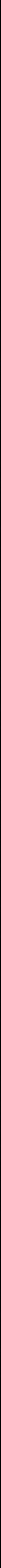

